\title{
The Extent of Factors Influencing Automobile Salesperson's Career Tenure in Malaysia
}

\author{
Osman M. Zain \\ International Islamic University Malaysia \\ Muhammad Tahir Jan \\ International Islamic University Malaysia
}

\begin{abstract}
Salesperson's tenure is a major issue for companies especially in today's era of high competition. A high rate of employee turnover is reported to impact organizational productivity and competitiveness. The present study aims to identify and test those factors which play an important role in salesperson's career tenure. For this purpose, data was collected from 400 sales personnel, working in various automobile companies, through self-administered questionnaire. The data analysis was conducted using SPSS and AMOS software. Factor analysis was performed to extract and decide on the number of factors underlying the measured variables of interest. Structural equation modelling (SEM) was then used to examine the variables and the fitness of proposed model. We found a significant positive impact of intrinsic motivation on job satisfaction and organizational commitment. Similarly, we also found the impact of organizational commitment on employee productivity and tenure. The findings of this study have a major implication for marketing organizations and more specifically for recruitment agencies.
\end{abstract}

Keywords: Salesperson, career, tenure, job satisfaction, intrinsic motivation, organizational commitment.

\section{Introduction}

For nearly 50 years market orientation was seen primarily as an organizational phenomenon. Market orientation was recognized in academic literature as early as the 1920s (Strong, 1925), and by the 1950s market orientation was viewed as an operation of the marketing concept at the organizational level (Borch, 1957). The initial interest in organizational market orientation was focused on the ability of top management to shape the values and orientation of their organizations (Felton, 1959). By the mid-1960s, empirical studies were beginning to measure the effects of market orientation, and for the next few years the emphasis moved to theory construction which examined the effects of organizational structure on organizational market orientation. In the early seventies, the importance of organizational market 
orientation was seen to diminish in the face of rapid technological change which reduced the advantages gained by responsiveness to an individual customer's needs (Tauber, 1974). Over the next decade, the focus of the literature moved inside the selling organization and began to examine the market orientation of the sales force as a consequence of evaluation and reward systems (Anderson and Chambers, 1985). This individual level of market orientation, referred to as salesperson customer orientation, is of great interest because of salespeople's direct contact with customers and the belief that this will impact sales outcomes. Continuing with their focus inside the selling orientation, researchers theorized that information flow within the organization facilitated organizational market orientation (Deshpande and Zaltman, 1982), and saw conflict as an inhibitor (Ruekert and Walker, 1987). In the 1980s, interest in relationship marketing brought increased attention to market orientation (Deshpande and Webster, 1989; Webster, 1988).

Over the last few decades, this shift in marketing from transaction orientation to a more relationship management orientation made it vital to understand the nature and quality of all channel interactions, especially, between the organization and the customer (JrZemanek and Pride, 1996). However, currently in marketing the focus is more on the relationships between organizations. Young and Wilkinson (1989) called it very unfortunate because the real focus of the exchange relationship may be found in customer-salesperson interpersonal relationship rather than inter-organizational relationship. Therefore, more focus should be given to this interpersonal relationship between the customers and salespersons (Anderson and Narus, 1984; 1990).

The current research, therefore, focuses on the significant factors that are influencing the salesperson tenure in the organization. For this purpose, an attempt is made to assess the degree of determinants factors that are influencing Salesmanship tenure.

\section{Literature Review}

Today, due to the rapid development in the information technology and communication sector, an ever changing and expanding set of challenges are faced by the salespeople. For example, the new emerging management practices and trends, organizational downsizing and re-engineering, quality improvement initiatives, learning and knowledge management, team orientation, and relationship marketing (Marshall et al., 2004), all these created an environment for the salespeople where they have to keep their selves up-to-date and well informed. Siguaw et al. (1994) further concluded that well informed salespeople are said to be more strongly committed to the organization, thus prolonging their tenure with that particular organization.

All these emerging new practices and initiatives have changed the traditional tasks of salespeople. Now the organizations emphasis on customer satisfaction and loyalty which results in organizational requirements of high level of involvement from the sales force, as the sales force represents the boundary-spanning group between selling firm and customers (Cortada, 1993; Leigh and Marshall, 2001; Rackham and DeVincentis, 1999). It is, therefore, necessary to understand those factors which can influence the salespersons' tenure in an organization. 


\section{Intrinsic Motivation}

A motivated person is considered to be energized or activated toward an end, whereas, an unmotivated person feels no stimulation or thrust to act (Ryan and Deci, 2000). The self-determination theory presented by Deci and Ryan (1985) distinguished between two main types of motivation, namely, intrinsic motivation and extrinsic motivation. Intrinsic motivation means doing a particular act because it is of inherited interest or joy to the subject. On contrary, extrinsic motivation refers to doing something because it leads to a separable outcome (Deci and Ryan, 1985; Ryan and Deci, 2000). According to Ryan and Deci (2000), both these distinct types of motivations can influence a person's quality of experience and performance when performing a particular act. However, special attention should be given to intrinsic motivation and the factors and forces that engender or undermine it, because intrinsic motivation results in high quality outcome and creativity (Ryan and Deci, 2000).

Many studies have focused on the outcomes of the decision regarding job, an individual make, based on the internal desires (intrinsic motivation) or the extent to which the choice was made with salient external factors (extrinsic motivation) such as family and preferences for location, etc. (O'Reilly and Caldwell, 1980). Salancik (1977) confirmed that when an individual make a decision (choose a job) based on the extrinsic motivational factors, the outcomes are likely to be valued less and the individual may be less committed as compare to that choice if it was made based on the intrinsic motivation. This research by Salancik (1977) illuminated the importance of intrinsic motivation in influencing an individual's job satisfaction and organizational commitment. The influence of intrinsic motivation was also investigated by other scholars (see O'Reilly and Caldwell, 1980).

A survey on MBA graduates were conducted by O'Reilly and Caldwell (1980). Their result showed that a decision made by these graduates in selecting a job, which is based on intrinsic motivation, positively impact job satisfaction and their commitment to the organization. On the other hand, if the decision is made based on the extrinsic factors, the subsequent satisfaction and commitment are not positively influenced (O'Reilly and Caldwell, 1980). However, O'Reilly and Caldwell (1980) confirmed the positive impact of salary (extrinsic motivation) on the future tenure intention. Winer and Schiff (1980) also reported that majority of the salespersons in their study were strongly motivated by making more money. Similar results are available in the literature that confirmed the positive impact of intrinsic motivation on job satisfaction and organizational commitment (see Lepper and Greene, 1975; Wortman, 1975). All these previous scholars agree that when an individual perceives the selected job based on extrinsic factors such as family or financial pressures, that individual may be less satisfied and less committed as compared to that when intrinsic motivation is involved in the process of selecting a job. In a similar manner, O'Reilly and Caldwell (1980) explicated that when a person choose a job for extrinsic rather than intrinsic reasons like, salary or location rather than opportunities for learning and advancement, his or her job satisfaction and organizational commitment will be lower than with a job selected based on intrinsic benefits.

The influence of intrinsic motivation on employee productivity has also been investigated by researchers (see Grant, 2008). In the beginning of $20^{\text {th }}$ century, scholars and practitioners believed that extrinsic factors like incentives, punishments, 
and rewards can accelerate employee persistence, performance, and productivity (see Heath, 1999; Steer et al., 2004). However, this concept was later altered by scholars when they began to propose that employee satisfaction, commitment, productivity, and intention to stay (tenure) can be enhanced if the work is inherently interesting and enjoyable for them (Deci, 1975; Deci and Ryan, 1985; Herzberg, 1966; McGregor, 1960), giving an entry to intrinsic motivation. Congruently, Grant (2008) also proposed that pro-social motivation will enhance if it is accompanied by intrinsic motivation and that will consequently positively impact productivity, hence confirming the influence of intrinsic motivation on employee productivity. In light of the arguments and importance of intrinsic motivation, that can be seen in the literature, we include this antecedent for the first time in the study related to salespeople. Therefore, we propose that:

H1: Intrinsic motivation will have a positive impact on job satisfaction

$\mathrm{H} 2$ : Intrinsic motivation will have a positive impact on organizational commitment

H3: Intrinsic motivation will have a positive impact on employee productivity

H4: Intrinsic motivation will have a positive impact on the tenure of employee

\section{Job Satisfaction}

The systematic studies on job satisfaction can be traced back to 1930s (Hoppock, 1935; Kornhauser and Sharp, 1932; Roethlisberger and Dickson, 1939). Many scholars explained job satisfaction in different ways. Some call it the extent to which employees feel about their job (see Odon et al., 1990), some call it the employee's feeling of contentment and discontentment for a job (see Demir, 2002), whereas some others call it a contribution of cognitive and affective reactions to the difference between what an employee actually receives compare to what he/she was expecting to receive (see Cranny et al., 1992).

Researchers (see Roethlisberger and Dickson, 1939) argued that job satisfaction increase productivity and organizational sustainability, but this statement is seriously questioned by others (Brayfield and Crockett, 1955; Iaffaldano and Muchinsky, 1985). The interest in job satisfaction is focused primarily on its impact on employee commitment, absenteeism, and turnover (Brooke and Price, 1989; Michaels and Spector, 1982; Mobley et al., 1978; Mowday et al., 1982; Mueller and Price, 1990; Price and Mueller, 1981, 1986; Steers, 1977). Even though the importance of job satisfaction in explaining these organizational behaviors has been questioned, job satisfaction remains as one of the most studied concepts in organizational research (Agho et al., 1993).

Numerous studies are report in literature that investigates the link between employee attitude (i.e., job satisfaction and organizational commitment) and work outcomes. For example, Locke (1976) focused on the link between job satisfaction and employee behaviors such as job performance and turnover or tenure. Similarly, the relationship between organizational commitment and employee behavior, namely, intention to leave, has also been explored (Mowday et al., 1982). It can also be found in the 
research by Lincoln and Kalleberg $(1985,1990)$, Mowday et al. (1982), Mueller et al. (1994), Price and Mueller (1986) and Wallace (1995) that satisfaction causes commitment. Employees with greater job satisfaction are said to be more committed to the entire organization. However, there is a lack of consensus among researchers on the causal precedence of satisfaction and commitment (Currivan, 1999). A depot of empirical evidence supports the causal superiority of satisfaction over commitment (Bluedorn, 1982; Lincoln and Kalleberg, 1990; Mowday et al., 1982; Mueller et al., 1994; Price and Mueller, 1986; Wallace, 1995; Williams and Hazar, 1986). On the other hand, some empirical studies have not confirmed this causal ordering (Currivan, 1999 ) and at times give causal priority to commitment over satisfaction (see Bateman and Strasser, 1984; Vandenberg and Lance, 1992).

A research by Shore and Martin (1989) is also worth mentioning, whereby they concluded that job satisfaction is strongly related to task related outcomes such as employee productivity and the intention of employee to stay or leave the organization. They further concluded that organization related attitude of an employee have a strong influence on the tenure compared to the job related attitude, like, job satisfaction. This influence of organizational related attitude and job related attitude was also supported by other scholars (see Porter et al., 1974; Wiener and Vardi, 1980). Jackofsky and Peters (1983) further argued that employees' intention to leave a particular job (tenure) is strongly influenced by employee satisfaction with the job. Literature also witnesses the impact of job satisfaction on employee productivity. For example, some researchers (see Petty et al., 1984) suggested that job satisfaction and employee productivity are related, whereas, some others (Iaffaldano and Muchinsky, 1985; Locke, 1976) concluded that there is a negligible relationship between job satisfaction and employee performance and productivity. In fact, promotion opportunities and earnings were identified as significant dissatisfiers (Shipley and Kiely, 2007). Based on the above arguments from the literature we propose that:

H5: Job satisfaction will have an impact on organizational commitment

H6: Job satisfaction will have an impact on employee productivity

H7: Job satisfaction will have an impact on tenure

\section{Organizational Commitment}

Researchers from various disciplines like, industrial psychology, sociology, organizational management, business administration, and public administration, have shown keen interest in the topic of commitment (Kaur and Sandhu, 2010). Commitment comes in different forms and has different foci. For example, Becker (1992) viewed the different foci in terms of commitment to the organization, top management, supervisors or the work group. Similarly, Cohen (2003) demonstrated importance of commitment in the workplace by providing a better understanding of how commitment affects employees' attitudes and performance. Different forms of commitment have been found to be important predictors of behaviors such as performance, organizational citizenship behavior, turnover, and absenteeism (Cohen, 2003). Of all the forms of commitment described in the literature, organizational commitment has received the most attention. However, in recent years, researchers 
also show interest in areas of commitment related to the occupation, the job, or the workgroup.

There is a considerable writing activity around organizational commitment and its ability to predict organizational outcomes like turnover, organizational performance, organizational effectiveness, organizational goals, and absenteeism (Angle and Perry, 1981; Cogliser et al., 2009; Colbert et al., 2008; Dale and Fox, 2008; Laschinger et al., 2001; Meyer and Allen, 1997; Mowday et al., 1982; Randall, 1990; Steers, 1977). High levels of organizational commitment have been linked to higher productivity conversely lower levels of organizational commitment have been linked to higher levels of absenteeism, turnover, and stress-related issues (Ward and Davis, 1995). Organizational commitment has been demonstrated to increase with employment tenure as well as age (Clark and Oswald, 1996; Cohen, 1993; Shore et al., 1990).

Many scholars (e.g. Chughtai and Zafar, 2006; Cohen, 2007; Mohapatra and Sharma, 2008; Steers, 1977) focused on identifying the variables that may have impact on individual's commitment. These researchers highlighted two main factors; age and tenure, can have influence on commitment. However, there are also contradicting reports of weak relationships between organizational commitment and age, and organizational commitment and tenure (see Cohen and Lowenberg, 1990; Mathieu and Zajac, 1990; Meyer et al., 2002). Researchers on salespersons reported a strong negative correlation between organizational commitment and intention to leave (Boles et al., 2012; Brown and Peterson, 1994; Johnston et al., 1990). Cohen (1993) explicated that this weak relationships might be the reason of considering both age and tenure time-related variables which represents similar effects and processes. Interestingly, various patterns of relationships exist between organizational commitment and age, and organizational commitment and tenure across different employment stages (Cohen, 1993; Gregersen, 1993; Winter et al., 2000; Kumar and Giri, 2009).

Literature also highlights that organizational commitment has a significant impact on productivity and performance (Balfour and Wechsler, 1996). In line with this, Warsi et al. (2009) suggest that management should design a more intelligent incentive programs along with addressing the issues of organizational commitment in order to elevate employee productivity. These incentives could focus on driving employee behavior toward achieving maximum productivity (Feldman and Landsman, 2007). As such, organizations are reportedly engaged in programs like; total quality management, employee involvement, job enrichment, and skill-based pay, as an effort to make employee builds strong organizational commitment resulting in enhanced productivity (Lawler, 1986, 1992). In light of the above discussion, we put forward the following propositions:

H8: Organizational commitment will have an impact on employee productivity

H9: Organizational commitment will have an impact on tenure

\section{Employee Productivity}

In the last few decades a lot of work has been done to investigate the antecedents and/or consequence of employee productivity. Scholars around the world try to come 
up with different relationships of employee related activities to the employee productivity and vice versa. For example, Medoff and Abraham (1980, 1981) investigated the relationship between experience and productivity, and wages and productivity. They found no positive relationship between experience and productivity, hence challenging the work of Mincer (1974). The traditional human capital interpretation by Mincer (1974) stated that experience raises wages because it enhances productivity. This idea was also supported by many other researchers (see Brown, 1989; Maranto and Rodgers, 1984), who agreed that there is a positive impact of experience on employee productivity. In a similar manner, the link between productivity and earning have also been examined by Frank (1984), and Weiss (1988), who found a significant influence of employee productivity on earning and the length of employee's stay with a particular organization (tenure). Holzer (1990) stated the reason for the contradicting results in the literature on employee productivity is because of the novelty of sample of workers. Measures of employee productivity are generally not available in most sets of data on employees, and when available, they are usually specific to a given set of workers (Holzer, 1990).

Holzer (1990) analyzed the data on performance (employee productivity), wages, and employee characteristics which he drawn from the Employment Opportunity Pilot Project (EOPP) survey of firm in 1980 and 1982. He reported that there is a significant positive effect of experience on wages and productivity. Similarly, there is a significant positive effect of tenure on employee productivity, in which he then concluded that employee productivity will increase in line with the employee length of stay with an organization, or in other words, employee tenure. These conflicting results and arguments call for further research in order to examine the link between employee productivity and tenure. We, therefore, propose that:

H10: Employee productivity will have an impact on tenure.

These employee-related phenomena do encompass a wide range of occupations as covered in many researches, but very few researches are related to salespersons' tenure (Wren, Berkowitz and Grant, 2014; Boles et., 2012; Shipley and Kiely, 2007; Flaherty and Pappas; 2002; Brown and Peterson, 1993). As such, this research will focus on the salespersons.

The literature review discussed above resulted in 10 relevant propositions which then highlight the constructs for the present study that focusses on salespersons. Thus, the purpose of this research is to explore the relationship among highlighted constructs; intrinsic motivation, job satisfaction, organizational commitment, employee productivity, and tenure. As a result a model that includes those constructs is proposed. (see Figure 1). 
Figure 1: Proposed Conceptual Model

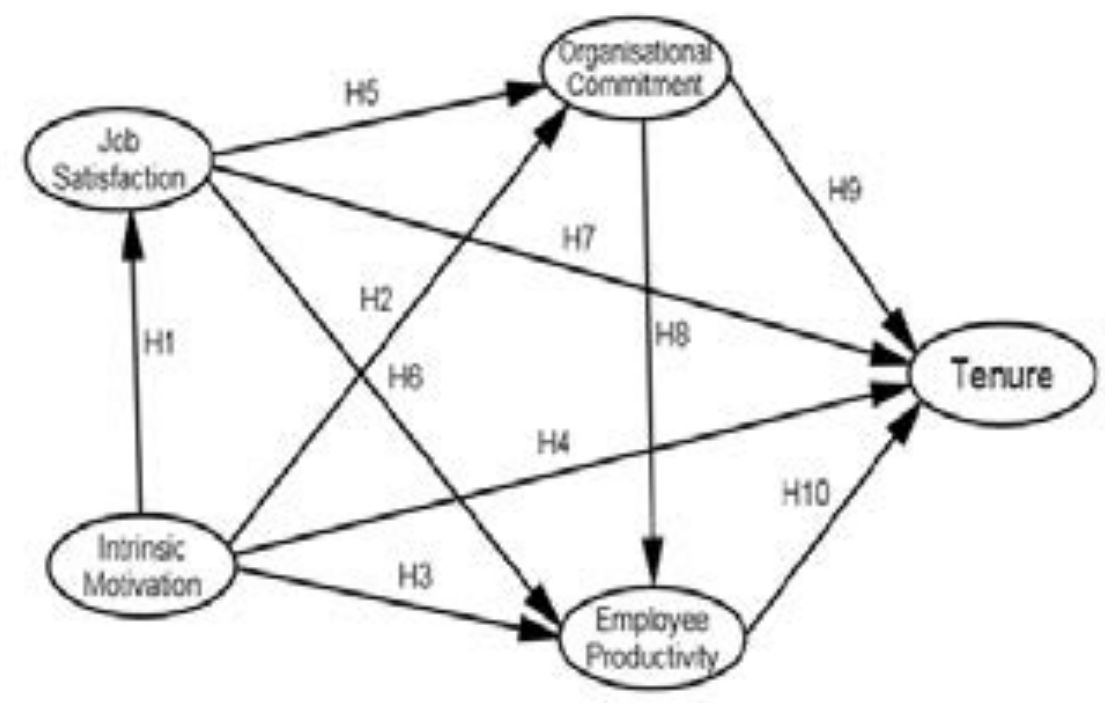

\section{Research Methodology}

For the current study, we have conducted a questionnaire survey to collect empirical data from various sales personnel employed in an automobile sector. This sector is chosen because, at present, it is one of the stable sectors in the Malaysia economy. The questions in the questionnaire are based on a review of the literature which were pre-tested and revised. The content validity of the questionnaire was deemed adequate. Questionnaire was divided into two parts, where the first part include questions related to intrinsic motivation, job satisfaction, organizational commitment, employee productivity, and tenure. In this part of the questionnaire respondents were asked to respond on a six-point rating scale from $1=$ strongly disagree to $6=$ strongly agree. The force rating scale is important to avoid the neutral responses by most respondents. The second part of the questionnaire was designed to acquire data on respondents' demographic.

A self-administered questionnaire was distributed randomly to the salespeople working in various automobile companies in Klang valley, Malaysia. A total of 400 questionnaires were distributed out of which 345 were returned, and finally 322 were selected which is adequate for data analysis purposes with AMOS. The remaining 23 were rejected due to the important missing data such as demographic information or if the entire section of the survey had been left incomplete.

\section{Results and Analyses}

\section{Demographic Profile}

From the total respondents, 231 are males $(71.7 \%)$. This is due to the fact that in automobile sector of Malaysia most of the sales personnel are males. Among the total respondents 169 were married which accounted for 52.5 percent. Majority of the respondents $(50.6 \%)$ were from the age group 25 to 34 , whereas, 41.9 percent had a minimum of certificate or diploma level education. In terms of ethnic background, the first major response was from Malays (42.9\%) and the second was from Chinese which accounted for 41.9 percent. Most of the respondents $(36.3 \%)$ are holding their 
current positions for duration of 1 to 3 years. Similarly, majority of the respondents $(34.8 \%)$ are working with their current organizations for duration of 1 to 3 years.

\section{Exploratory Factor Analysis}

The next step considered necessary in the present research was exploratory factor analysis (hereafter, EFA). Therefore, we performed EFA with Varimax rotation to examine if the items for a construct share a single underlying factor (i.e., are unidimensional). EFA was employed on all the items of the questionnaire to determine the possible underlying factors. During EFA all those items were deleted which did not satisfy the criteria of above 0.5 loading and below 0.35 cross-loading (Hair et al., 2010).

The Kaiser-Meyer-Olkin (KMO) measure of sampling adequacy was 0.928, indicating that the present data were suitable for principle component analysis. Similarly, Bartlett's Test of Sphericity was significant at $p<0.001$, indicating sufficient correlation between the variables. The results of the EFA indicated a clean five-factor structure using the criteria of an eigenvalue greater than 1 . The extracted factors account for 63.158 per cent of the total variance. All factor loadings were generally high, and the lowest loading was 0.514 . The resulting factor loadings are shown in Table 1 with all those less than 0.5 suppressed. All items loaded onto the expected factors as they were originally designed. Factors loading were all higher than 0.5 on its own factor and therefore each item loaded higher on its associated construct than on any other construct (see Table 1). This supported the discriminant validity of the measurement. In the same Table, we also present the reliability for each construct using Cronbach's alpha as suggested by scholars (Byrne, 2010; Hair et al., 2010; Kline, 2011; Pallant, 2007). The result of the present research showed that the Cronbach's coefficient alphas ranging from 0.808 to 0.940 indicating good subscale reliability and internal consistency of the items (see Table 1).

Table 1: Results of Exploratory Factor Analysis

\section{Component}

\begin{tabular}{lccccc}
\cline { 2 - 5 } $\begin{array}{l}\text { Items } \\
\text { (Variables) }\end{array}$ & $\begin{array}{c}\text { Factor 1 } \\
\text { Organizational } \\
\text { Commitment }\end{array}$ & $\begin{array}{c}\text { Factor 2 } \\
\text { Employee } \\
\text { Productivity }\end{array}$ & $\begin{array}{c}\text { Factor 3 } \\
\text { Job } \\
\text { Satisfaction }\end{array}$ & $\begin{array}{c}\text { Factor 4 } \\
\text { Tenure }\end{array}$ & $\begin{array}{c}\text { Factor 5 } \\
\text { Intrinsic } \\
\text { Motivati } \\
\text { on }\end{array}$ \\
\hline OC7 & .747 & & & \\
OC12 & .740 & & & \\
OC6 & .740 & & & \\
OC3 & .739 & & & \\
OC10 & .708 & & & \\
OC13 & .701 & & & \\
OC4 & .679 & & & \\
OC2 & .649 & & & \\
OC17 & .648 & & & \\
OC1 & .647 & & & \\
OC9 & .636 & & & \\
OC20 & .578 & & & \\
OC11 & .572 & & & \\
\hline
\end{tabular}




\begin{tabular}{|c|c|c|c|c|c|}
\hline & $\begin{array}{c}\text { Factor } 1 \\
\text { Organizational } \\
\text { Commitment }\end{array}$ & $\begin{array}{c}\text { Factor } 2 \\
\text { Employee } \\
\text { Productivity }\end{array}$ & $\begin{array}{c}\text { Factor } 3 \\
\text { Job } \\
\text { Satisfaction }\end{array}$ & $\begin{array}{c}\text { Factor } 4 \\
\text { Tenure }\end{array}$ & $\begin{array}{c}\text { Factor 5 } \\
\text { Intrinsic } \\
\text { Motivati } \\
\quad \text { on }\end{array}$ \\
\hline OC8 & .535 & & & & \\
\hline EP30 & & .799 & & & \\
\hline EP28 & & .765 & & & \\
\hline EP31 & & .746 & & & \\
\hline EP29 & & .743 & & & \\
\hline EP27 & & .726 & & & \\
\hline EP26 & & .716 & & & \\
\hline EP25 & & .686 & & & \\
\hline JS20 & & & .665 & & \\
\hline JS16 & & & .640 & & \\
\hline JS13 & & & .635 & & \\
\hline JS21 & & & .606 & & \\
\hline JS22 & & & .579 & & \\
\hline JS17 & & & .558 & & \\
\hline JS14 & & & .533 & & \\
\hline $\mathrm{T} 2$ & & & & .854 & \\
\hline $\mathrm{T} 1$ & & & & .813 & \\
\hline $\mathrm{T} 3$ & & & & .787 & \\
\hline $\mathrm{T} 5$ & & & & .676 & \\
\hline $\mathrm{T} 4$ & & & & .514 & \\
\hline IM40 & & & & & .740 \\
\hline IM32 & & & & & .728 \\
\hline IM33 & & & & & .704 \\
\hline $\begin{array}{l}\text { Initial } \\
\text { Eigenvalues }\end{array}$ & 14.769 & 2.895 & 2.088 & 1.698 & 1.287 \\
\hline $\begin{array}{l}\% \text { of } \\
\text { Variance }\end{array}$ & 21.574 & 14.833 & 10.597 & 8.375 & 7.779 \\
\hline $\begin{array}{l}\text { Cumulative } \\
\%\end{array}$ & 21.574 & 36.407 & 47.004 & 55.379 & 63.158 \\
\hline Reliability & 0.940 & 0.912 & 0.836 & 0.808 & 0.815 \\
\hline
\end{tabular}

\section{Confirmatory Factor Analysis}

After EFA and reliability test of the extracted factors, confirmatory factor analysis was undertaken before full structural modelling, hence adopting two-stage modelling approach. In the two-stage modelling approach, the measurement model is specified and fitted before doing the same for a full-fledged structural model. Byrne (2010) and Hair et al. (2010) recommended these two phases in structural equation modelling because of the ease and accuracy of fitting the structural model once the measurement model is successfully specified and fitted. For this purpose AMOS software was used to perform Confirmatory Factor Analysis (CFA) on all the measuring items retained by EFA. 
A review of the measurement model (see Figure 2) shows that there are no offending estimates and the results of fit indices also support the proposed model. With a normed chi-square $\left(\chi^{2} / \mathrm{df}\right)$ value of $2.422\left(\chi^{2}=343.991\right.$, $\left.\mathrm{df}=142\right)$, which is within maximum point of 5.0, the measurement model is attested to be fit. Moreover, the baseline fit indices are also more than the 0.90 cut-off point, i.e., $\mathrm{CFI}=0.935, \mathrm{GFI}=$ 0.906 , indicating a good fit of the measurement model. Finally, RMSEA value of 0.067 is clearly below the cut-off value of 0.08 , indicating a good fit of the measurement model.

\section{Figure 2: Confirmatory Factor Analysis}

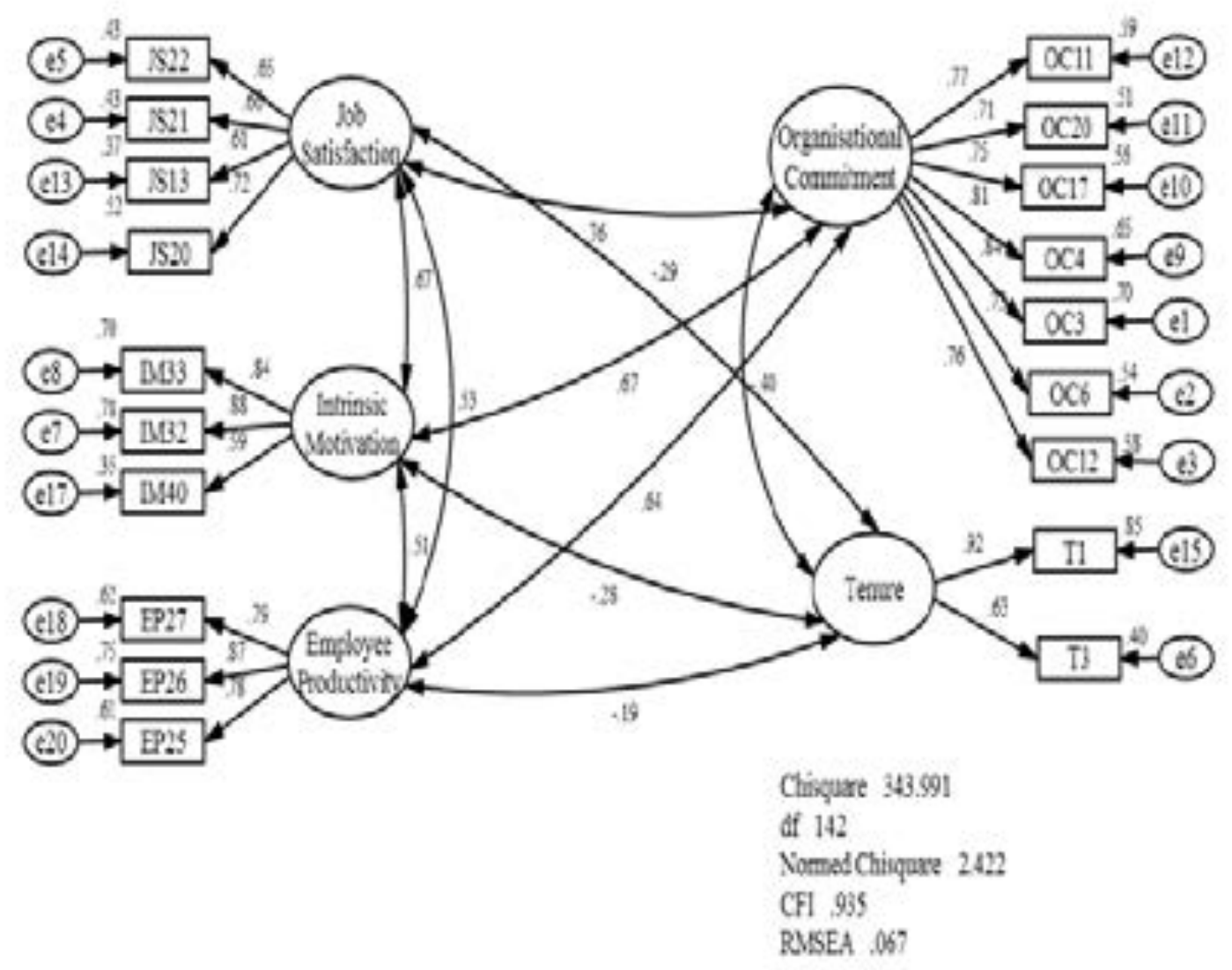

After achieving the good fit of measurement model, the next step was to test the hypothesized causal relationships among the constructs of the model. This was done through structural equation modelling using AMOS software. The maximum likelihood estimates (MLE) method was used after the constructs satisfied the criterion of multivariate normality (Bagozzi and $\mathrm{Yi}, 1988$ ). Therefore, for all the constructs, test of normality, namely, skewness, kurtosis, and Mahalanobis distance $\left(D^{2}\right)$ statistics were conducted. These indicated no departure from normality. Thus, as normality was confirmed for all the constructs, we proceeded to use the MLE method to estimate the model.

The baseline structural model is depicted in Figure 3. The model was assessed based on the following indices: the chi-square test, the comparative fit index (CFI), and the root mean square error of approximation (RMSEA), as per the suggestions of many scholars (Byrne, 2010; Hair et al., 2010; Kline, 2011). In addition, the path coefficients were also assessed both for statistical significance $(p<0.05)$ and practical 
significance $(\beta>0.20)$. The results of this structural model yielded acceptably high goodness-of-fit indices. This indicated that the hypothesized model fits the observed data well. The normed chi-square value $(\mathrm{CMIN} / d f)$ value for the current hypothesized model was 2.422 which are well below the value of 5.0 often indicated as the benchmark in SEM literature. Similarly, other goodness-of-fit indices; CFI resulted an acceptable value of 0.935 , whereas RMSEA yielded a value of 0.067 , which is also below the threshold value of 0.08 . All these indicate a good fit of the hypothesized model.

\section{Figure 3:Baseline Structural Model}

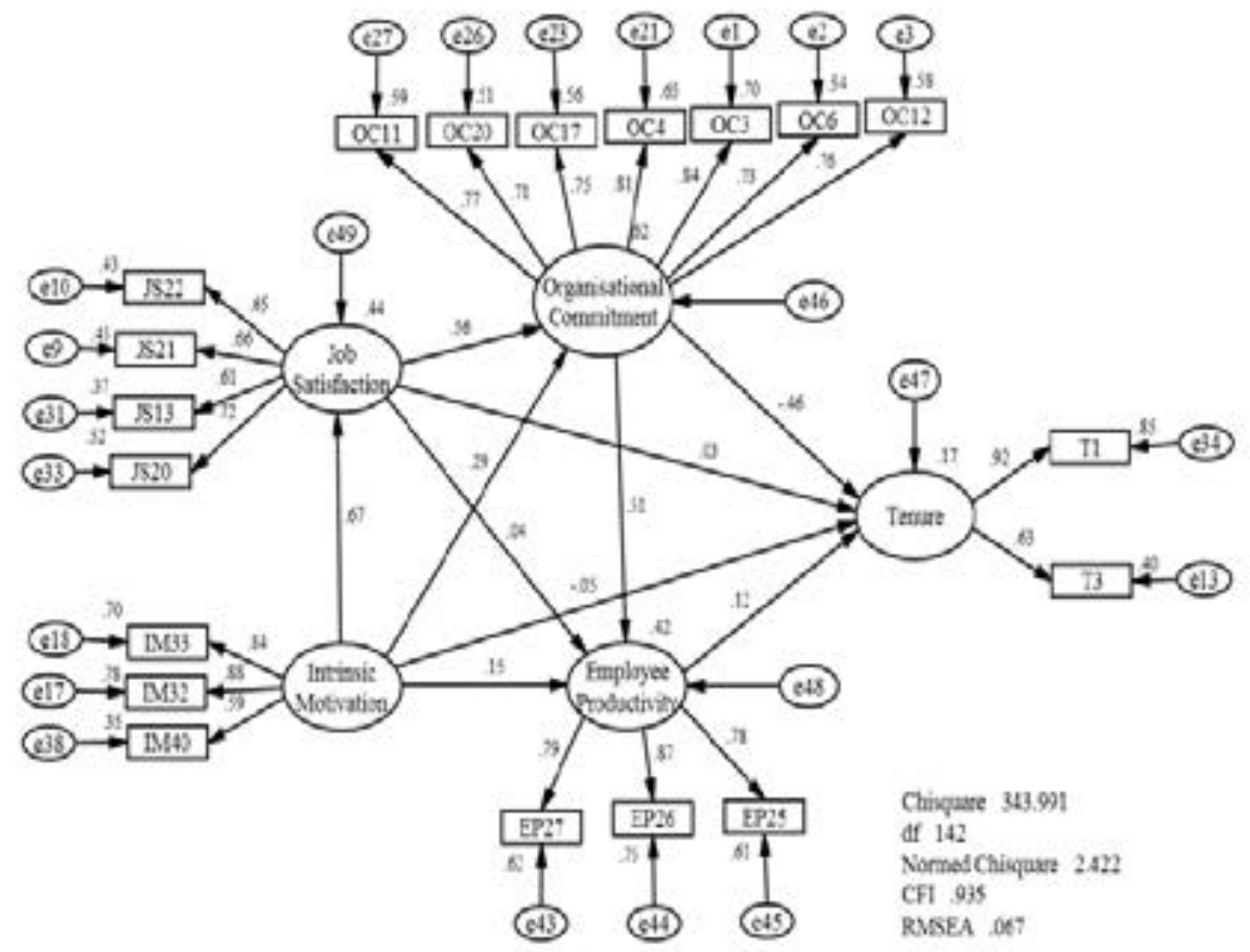

A more detailed analysis of the results and measures for model fit are reported in Table 2. Since there is no definitive standard of it, a variety of indices are provided along with suggested guidelines

Table 2:Estimates of the Hypothesized Model

\begin{tabular}{lccccc}
\hline Structural path & $\begin{array}{l}\text { Hypothesized } \\
\text { Relationship }\end{array}$ & $\begin{array}{l}\text { Std. Reg. } \\
\text { Weight }\end{array}$ & S. E. & C. R. & P \\
\hline $\begin{array}{l}\text { Job satisfaction }<\text { Intrinsic } \\
\text { motivation }\end{array}$ & $\mathrm{H} 1^{\mathrm{s}}$ & .666 & .065 & 8.712 & $* * *$ \\
\hline $\begin{array}{l}\text { Organizational commitment } \leftarrow \\
\text { Intrinsic motivation }\end{array}$ & $\mathrm{H} 2^{\mathrm{s}}$ & .295 & .074 & 4.004 & $* * *$ \\
\hline $\begin{array}{l}\text { Organizational commitment } \leftarrow \text { Job } \\
\text { satisfaction }\end{array}$ & $\mathrm{H} 5^{\mathrm{s}}$ & .561 & .104 & 6.400 & $* * *$ \\
\hline $\begin{array}{l}\text { Employee productivity } \leftarrow \text { Intrinsic } \\
\text { motivation }\end{array}$ & $\mathrm{H} 3^{\mathrm{ns}}$ & .145 & .079 & 1.737 & .082 \\
\hline Employee productivity $\leftarrow$ Job satis & $\mathrm{H} 6^{\mathrm{ns}}$ & .044 & .122 & .393 & .694 \\
\hline
\end{tabular}


Table 2:Estimates of the Hypothesized Model (Cont)

\begin{tabular}{lccccc}
\hline Structural path & $\begin{array}{l}\text { Hypothesized } \\
\text { Relationship }\end{array}$ & $\begin{array}{l}\text { Std. Reg. } \\
\text { Weight }\end{array}$ & S. E. & C. R. & P \\
\hline $\begin{array}{l}\text { Employee productivity } \leftarrow \\
\text { Organizational commitment }\end{array}$ & $\mathrm{H} 8^{\mathrm{s}}$ & .509 & .096 & 4.933 & $* * *$ \\
\hline Tenure $\leftarrow$ Intrinsic motivation & $\mathrm{H} 4^{\text {ns }}$ & -.051 & .089 & -.525 & .600 \\
\hline Tenure $\leftarrow$ Job satisfaction & $\mathrm{H} 7^{\mathrm{ns}}$ & .028 & .137 & .233 & .823 \\
\hline Tenure $\leftarrow$ Organizational Commitment & $\mathrm{H} 9^{\mathrm{s}}$ & -.459 & .134 & -3.114 & .002 \\
\hline Tenure $\leftarrow$ Employee productivity & $\mathrm{H} 10^{\text {ns }}$ & .116 & .086 & 1.320 & .187 \\
\hline Statistic & & Suggested & & Obtained & \\
\hline Chi-square significance & & $\geq 0.05$ & & 0.000 & \\
\hline Normed chi-square $(\mathrm{CMIN} / \mathrm{d} f)$ & & $\leq 5.00$ & & 2.422 & \\
\hline Comparative fit index (CFI) & & $\geq 0.90$ & & 0.935 & \\
\hline Goodness-of-fit index (GFI) & $\geq 0.90$ & & 0.906 & \\
\hline Root mean error square of approximation (RMSEA) & $\leq 0.08$ & & 0.067 & \\
\hline s = Supported, ns = Not supported & & & & \\
\hline
\end{tabular}

Based on the results of the hypothesis model, five out of total ten hypotheses are supported. Among the five statistically significant hypotheses, namely, H1, H2, H5, $\mathrm{H} 8$, and $\mathrm{H} 9$, four hypotheses were significant at $p<0.001$, whereas only one hypothesis (H9) resulted in significance at level $p<0.01$. For the remaining hypotheses; $\mathrm{H} 3, \mathrm{H} 4, \mathrm{H} 6, \mathrm{H} 7$, and $\mathrm{H} 10$, the results did not provide sufficient evidence to support them.

\section{Discussions}

The results from this study support past studies, (namely, Salancik, 1977; O'Reilly and Caldwell, 1980); Lepper and Greene, 1975; Wortwan, 1975) whereby intrinsic motivation do have positive impact on job satisfaction, and organizational commitment. However, these past studies quoted above covered a wide range of occupation, and very few are with reference to salespeople. Shipley and Kiely (2007) reported that for most salespeople, they are more motivated by money (extrinsic motivation) with respect to tenure. And so as the results of the present study that lead to the rejection of H3 and H4. In similar vein, Winer and Schiff (1980) reported that the industrial salespersons in their study placed "making money" as their second extremely strong motivator. Their first extremely strong motivator is the "selfsatisfaction in doing a good job." Thus, the results from present study concur with that of Winer and Schiff (1980), and Shipley and Kiely (2007) explaining that the extrinsic rather than intrinsic motivation is prominent in motivating salespersons in their jobs. Thus, it is reported that salesforce management in the People's Republic of China uses monetary motivation to encourage salespeople improve performance (Siu 2007), and keeping them in their jobs.

The results from this study indicate that job satisfaction has positive impact on organizational commitments but not necessarily on productivity or on tenure. Perhaps, the researcher should dissect job satisfaction on into several dimensions. In line with this, Purani and Sahadev (2008) identified five dimensions through their qualitative study on salespersons in India. However, they also reported that the means of satisfaction on each of the five dimensions are above 3.0 on a Likert scale, with 4.249 on career development prospect of the company. Job satisfaction thus, has 
positive impact on tenure, with the existence of a clear career path development within an organization (Purani and Sahadev, 2008). Should the present study was to also include some extrinsic motivation or pay dimension of satisfaction, the results would have shown a positive impact on to tenure by job satisfaction. This contention is supported by the recent study of Mohamad Issa, Ahmad and Gelaidan (2013), whereby they reported that pay satisfaction has the highest impact on the decision to leave or to keep staying in the organization.

The results of the present study support previous findings on the impact of organizational commitment on tenure. Marsh and Mannari (1977) reported that organizational commitment had high impact tenure especially among the males. The female do have commitment to their organization but situational reasons do not permit them to stay longer than males. This was supported by Berkowitz et al. (2014), who acknowledged that organizational commitment as the most influential variable in relation to tenure.

\section{Conclusion and Implications}

Previously researchers have explored those factors which are responsible for the tenure of employees from a wide range occupation in organizations. This research is unique in a sense that it extracted those factors from the literature which are considered imperative for the tenure of the employees in an organization, and then empirically tested those factors to validate a model for salesperson career tenure. However, the results of the study do indicate that sales occupation is a bit different from other occupations. The employees in this sector are highly motivated by pay in order to lower their intention to leave.

Nevertheless, our findings revealed that intrinsic motivation positively affect job satisfaction and organizational commitment, meaning that, for a salesperson to be contented with his/her job he/she needs to be motivated intrinsically. Similarly, for a salesperson to be committed to the organization, he/she needs to be intrinsically motivated. This particular finding is congruent with previous research which states that if an individual is intrinsically motivated toward his job, he will have higher level of job satisfaction and organizational commitment (Salancik, 1977). Lepper and Greene (1975) and O'Reilly and Caldwell (1980) also found a positive impact of intrinsic motivation on job satisfaction and organizational commitment, hence confirming the importance of intrinsic motivation. This finding is of prime importance to the employers and recruiting agencies in a sense that they have to evaluate the candidates (job seekers/ applicants) in such a way to find out how motivated an applicant is intrinsically toward the offered job. In return, if intrinsically motivated individuals are hired, maximum productivity will be resulted (Grant, 2008). But, between the two motivation types, extrinsic motivation has the highest impact on tenure (Mohamad Issa, Ahmad and Gelaidan, 2013).

Another worth mentioning finding of the present study is the positive impact of organizational commitment on employee productivity. This is also in accordance with the previous research, for example, Ward and Davis (1995) also found that high levels of organizational commitment result in high employee productivity. Similarly, Balfour and Wechsler (1996) and Warsi et al. (2009) also emphasized on the importance of organizational commitment in elevating employee productivity. Based 
on the aforementioned finding it is suggested that organizations should design such policies which enhance employee commitment to their organization because organizational commitment leads to higher productivity and organizational sustainability. Management should also have a clear career development program for their sales people in an effort to maintain their loyalty to the organization. In addition, the remuneration scheme should also be attractive enough because researches have been highlighting the importance of pay with respect to tenure.

The proposed theory should be modified by the inclusion of few pertinent dimensions of job satisfaction, and to include both intrinsic and extrinsic motivations in the model. Literature reports the existence of few salient dimensions of job satisfaction, and also the major role of extrinsic motivation factors such as pay in determining the length of stay with organization. These are the few limitations of our study. We also focused on the salesperson of automobile sector which the results may be different from the salesperson of other industry categories, for example insurance or other consumer goods sectors.

It is therefore suggested that future study should rectify the shortcomings of the present study, and to expand its sample to include salesperson from other sectors of the consumer products or services. This will also enable the researcher(s) to compare the findings between sectors.

\section{References}

Agho, A. O., Muller, C. W., and Price, J. L. (1993). "Determinants of employee job satisfaction: An empirical test of a causal model." Human Relations 46 (8), 1007-127.

Anderson, J. C., and Narus, J. A. (1990). "A Model of Distributor Firm and Manufacturer firm Working Partnerships." Journal of Marketing 54 (1), 42-58.

Anderson, J. C., and Narus, J. A. (1984). "A Model of The Distributor-Manufacturer Working Relationships." Journal of Marketing 48 (4), 62-74.

Anderson, P., and Chambers, T. (1985). "A Reward/ Measurement Model of Organizational Buying Behavior." Journal of Marketing 49, 7-23.

Angle, H. L., and Perry, J. L. (1981). "An Empirical Assessment of Organizational Commitment and Organizational Effectiveness." Administrative science Quarterly 26 (1), 1-14.

Bagozzi, R., and Yi, Y. (1988). "On the Evaluation of Structural Equation Models." Journal of the Academy of Marketing Science. 16 (1), 74-94.

Balfour, D., and Wechsler, B. (1996). "Organizational Commitment." Public Productivity and Management Review 19, 256-277.

Bateman, T. S., and Strasser, S. (1984). "A Longitudinal Analysis of The Antecedents of Organizational Commitment." Academy of Management Journal 27, 95-112.

Becker, T. E. (1992). "Foci and Bases of Commitment: Are They Distinctions Worth Making?" Academy of Managment Journal 35 (1), 232-244. 
Bluedorn, A. C. (1982). The Theories of Turnover: Causes, Effects, and Meaning. Research in the sociology of organizations $1,75-128$.

Boles, J.S., Dudley, G.S., Onyemah, V., and Weeks, W.A. (2012). "Sales Force Turnover And Retention: A Research Agenda." Journal of Personnal Selling and Sales Management. 32, 1, $131-140$.

Borch, F. (1957). "The marketing philosophy as a way of business life." in E. Marting, and A. Newgarden (eds.), The Marketing Concept: Its Meaning to Management (pp. 3-16). New York, NY: American Management Association.

Brayfield, A. H., and Crockett, W. H. (1955). "Employee attitudes and employee performance." Psychological Bulletin, 52, 396-424.

Brooke, P. P., and Price, J. L. (1989). "The determinants of employee absenteeism: An empirical test of a causal model." Journal of Occupational Psychology , 62, 1-19.

Brown, J. N. (1989). "Why do wages increase with tenure?" American Economic Review 971-991.

Brown, S.P. and Peterson, R.A. (1994). "The Effect of Effort on Sales Performance and Job Satisfaction. " Journal of Marketing. 58, (2), 70-80.

Byrne, B. M. (2010). Structural Equation Modeling With AMOS: Basic Concepts, Applications, and Programming (2nd ed.). New York, NY: Taylor and Francis Group.

Chughtai, A., and Zafar, S. (2006). "Antecedents and Consequences of Organizational Commitment Among Pakistani University Teachers." Applied H.R.M Research , 11, 39-64.

Clark, A. E., and Oswald, A. J. (1996). "Satisfaction And Comparison Income." Journal of Public Economics. 61 (3), 359-381.

Cogliser, C. C., Schriesheim, C. A., Scandura, T. A., and Gardner, W. L. (2009). "Balance in leader and follower perceptions of leader-member exhange: Relationships with performance and work attitudes." The Leadership Quarterly 20 (3), 452-465.

Cohen, A. (2007). "Commitment before and after: An evaluation and reconceptualization of organizational commitment." Human Resource Management Review 17, 336-354.

Cohen, A. (2003). Multiple commitment in the workplace: An integrated approach. Mahwah. NJ: Lawrence Erlbaum Associates.

Cohen, A. (1993). "Organizational commitment and turnover: A meta analysis." Academy of Management Journal 36(5), 1140-1157.

Cohen, A., and Lowenberg, G. (1990). "A Reexamination of the side-bet theory as applied to organizational commitment: A meta analysis." Human Relations 43, 1015-1050.

Colbert, A. E., Kristof-Brown, A. L., Bradley, B. H., and Barrick, M. R. (2008). "CEO transformational leadership: The role of goal importance congruence in top management teams." Academy of Management Journal 51 (1), 81-96.

Cortada, J. W. (1993). TQM for Sales and Marketing Management. New York, NY: McGraw-Hill.

Cranny, C. J., Smith, R. C., and Stone, E. F. (1992). Job satisfaction: How people feel about their jobs and how it affects their performance. New York: Lexington. 
Currivan, D. B. (1999). "The causal order of job satisfaction and organizational commitment in models of employees turnover." Human Resource Managment Review 9 (4), 495524.

Dale, K., and Fox, M. L. (2008). "Leadership style and organizational commitment: Mediating effect of role stress." Journal of Managerial Issues 20 (1), 109-131.

Deci, E. L., and Ryan, R. M. (1985). Intrinsic motivation and self-determination in human behavior. New York, NY: Plenum.

Demir, M. C. (2002). "Job satisfaction of nurses, working at Turkish Military Forces Hospitals." Military Medicine. 167, 402-404.

Deshpande, R., and Webster, F. E. (1989). "Organizational culture and marketing: defining the research agenda." Journal of Marketing , 53, 3-15.

Deshpande, R., and Zaltman, G. (1982). "Factors affecting the use of marketing research information: a path analysis." Journal of Marketing Research. 19, 14-31.

Feldman, J., and Landsman, D. L. (2007). "The benefits of incentives". Talent Management Magazine. 28-31.

Felton, A. P. (1959). "Making the marketing concept work." Harvard Business Review 37, 55-65.

Flaherty, K.E. and Pappas, J.M. (2002). "The Influence of Career stage on Job Attitudes: Toward a Contigency Perspective." Journal of Personal Selling and Sales management. 22 (3) 135 - 43.

Frank, R. (1984). "Are workers paid their marginal products?" American Economic Review. 549-571.

Grant, A. M. (2008). "Does Intrinsic Motivation Fuel the Prosocial Fire? Motivational Synergy in Predicting Persistence, Performance, and Productivity." Journal of Applied Psychology. 93 (1), 48-58.

Gregersen, H. B. (1993). "Multiple commitments at work and extra role behaviour during three stages of organizational tenure." Journal of Business Research. 26, 31-47.

Hair, J. F., Black, W. C., Babin, B. J., and Anderson, R. E. (2010). Multivariate Data Analysis (7th ed.). New Jersey: Pearson Prentice Hall.

Heath, C. (1999). "On the social psychology of agency relationships: Lay theories of motivation overemphasize extrinsic incentives." Organizational Behavior and Human Decision Processes. 78, 25-62.

Herzberg, F. (1966). Work and the nature of man. Cleveland, OH: World Publishing.

Holzer, H. J. (1990). "The Determinants of Employee Productivity and Earnings". Industrail Relations. 29 (3), 403-422.

Hoppock, R. (1935). Job Satisfaction. New York: Harper and Brothers.

Iaffaldano, M. T., and Muchinsky, P. M. (1985). "Job satisfaction and job performance: a meta-analysis." Psychological Bulletin. 97, 251-273. 
Jackofsky, E. F., and Peters, L. H. (1983). "Job turnover versus company turnover: Reassessment of the march and Simon Participation Hypothesis." Journal of Applied Psychology. 68, 490-495.

Jr Zemanek, J. E., and Pride, W. M. (1996). "Distingushing between manufacturer power and manufacturer salesperson power." Journal of Business and Industrail Marketing 11 (2), 20-36.

Johnston, M.W., Parasuraman, A., Futrell, C.M., and Black, W.C., (1990). "A Longitudinal Assessment of the Impact of Selected Organizational Influences on Salespeoples' Organizational Commitment During Early Employment," Journal of Marketing Research. 27(3), 333-344.

Kaur, K., and Sandhu, H. S. (2010). "Career Stage Effect on Organizational Commitment: Empirical Evidence from Indian Banking Industry," International Journal of Business and Management, 5 (12), 141-152.

Kline, R. B. (2011). Principles and Practice of Structural Equation Modeling (3rd ed.). New York, NY: The Guilford Press.

Kornhauser, A., and Sharp, A. (1932). "Employee attitudes: suggestions from a study in a factory." Personnel Journal 10, 393-401.

Kumar, B. P., and Giri, V. N. (2009). "Effect of age and experience on job satisfaction and organizational commitment." The Icfai Journal of Organizational Behaviour 8, 2836.

Laschinger, H. K., Finegan, J., and Shamian, J. (2001). "The impact of workplace empowerment, organizational trust on staff nurses' work satisfaction and organizational commitment." Health Care Management Review (Summer) 26 (3), 7 23.

Lawler, E. (1986). High involvement management. San Francisco: Jossey-Bass.

Lawler, E. (1992). The ultimate advantage. San Francisco: Jossey-Bass.

Leigh, T. W., and Marshall, G. W. (2001). "Research Priorities in Sales Strategy and Performance." Journal of Personal Selling and Sales Management 21, 83-93.

Lepper, M. R., and Greene, D. (1975). "Turning play into work: effects of adult surveillance and extrinsic rewards on childern's intrinsic motivation." Journal of Personality and Social Psychology, 31, 479-486.

Lincoln, J. R., and Kalleberg, A. L. (1990). Culture, control and commitment: A study of work organization and work orientations in the United States and Japan. Cambridge: Cambridge University Press.

Lincoln, J. R., and Kalleberg, A. L. (1985). "Work organization and workforce commitment: A study of plants and employees in the U.S. and Japan." American Sociological Review. 50, 738-360.

Locke, E. A. (1976). "The nature and causes of job satisfaction." in M. D. Dunnette (eds.), Handbook of industrial and organizational psychology. Chicago, IL: Rand McNally.

Mohamad Issa, D. A Rahim, Ahmad, Fais, and Gelaidan, Hamid M.(2013). "Job Satisfaction and Turnover Intention Based on Sales Person Standpoint." Middle-East Journal of Scientific Research. 14 (4): 525-531. 
Maranto, C., and Rodgers, R. (1984). "A test of the on-the-job training hypothesis." Journal of Human Resources. 341-357.

Marshall, G. W., Lassk, F. G., and Moncrief, W. C. (2004). "Salesperson job involvement: do demographic, job situational, and market variables matter?" Journal of Business and Industrial Marketing. 19 (5), 337-343.

Mathieu, J. E., and Zajac, D. M. (1990). "Review and meta analysis of the antecedents, correlates, and consequences of organizational commitment." Psychological Bulletin. 108, 171-194.

McGregor, D. (1960). The human side of the enterprise. New York: McGraw-Hill.

Medoff, J., and Abraham, K. (1981). "Are those paid more really more productive? The case of experience." Journal of Human Resources. 186-216.

Medoff, J., and Abraham, K. (1980). "Experience, Performance and Earnings." Quarterly Journal of Economics. 703-736.

Meyer, J. P., and Allen, N. J. (1997). Commitment in the workplace: Theory, research, and application. Thousand Oaks, CA: Sage Publications.

Meyer, J. P., Stanley, D. J., herscovitch, L., and Topolnytsky, L. (2002). "Affective, Continuance, and normative commitment to the organization: A meta analysis of antecedents, correlates, and consequences." Journal of Vocational behaviour. 61, 2052.

Michaels, C. E., and Spector, P. E. (1982). "Causes of employee turnover: A test of the Mobley, Griffeth, Hand, and Meglino model." Journal of Applied Psychology. 67, 53-59.

Mincer, J. (1974). Schooling, experience, and earnings. New York: National Bureau of Economic Research.

Mobley, W. H., Horner, S. O., and Hollingsworth, A. T. (1978). "An evaluation of precursors of hospital employee turnover." Journal of Applied Psychology. 63 (4), 408-414.

Mohapatra, M., and Sharma, B. R. (2008). "Drivers of organizational commitment among managers of industrial organizations: A case study." Global Business Review. 9 (1), $51-63$.

Mowday, R. T., Porter, L. W., and Steers, R. M. (1982). Employee-organization linkages: The psychology of commitment, absenteeism, and turnover. New York, NY: Academic Press.

Mueller, C. W., and Price, J. L. (1990). "Economic, psychological, and sociological determinants of voluntary turnover." The Journal of Behavioral Economics. 19, 321335 .

Mueller, C. W., Boyer, E. M., Price, J. L., and Iverson, R. D. (1994). "Employee attachment and noncoercive conditions of work: The case of dental hygenists." Work and Occupations. 21, 179-212.

Odon, R. Y., Boxx, W. R., and Dunn, M. G. (1990). "Organizational cultures, commitment, satisfaction and cohesion." Public and Management Review. 14, 157-168. 
O'Reilly, C. A., and Caldwell, D. F. (1980). "Job Choice: The Impact of Intrinsic and Extrinsic Factors on Subsequent Satisfaction and Commitment." Journal of Applied Psychology. 65 (5), 559-565.

Pallant, J. (2007). SPSS Survival Manual. New South Wales: Allen and Unwin.

Porter, L. W., Steers, R. M., Mowday, R. T., and Boulian, P. v. (1974). "Organizational commitment, job satisfaction, and turnover among psychiatric technicians." Journal of Applied Psychology. 59, 603-609.

Price, J. L., and Mueller, C. W. (1981). "A causal model of turnover for nurses." Academy of Management Journal. 24, 543-563.

Price, J. L., and Mueller, C. W. (1986). Handbook of organizational measurement. Cambridge, MA: Ballinger.

Purani, Keyoor, and Sahadev, Sunil. (2008). "The moderating role of industrial experience in the job satisfaction, intention to leave relationship: an empirical study among salesmen in India." Journal of Business \& Industrial Marketing, 23/7. 475 - 485.

Rackham, N., and DeVincentis, J. (1999). Rethinking the Sales Force: Redefining Selling to Create and Capture Customer Value. New York, NY: McGraw-Hill.

Randall, D. M. (1990). "The consequences of organizational commitment: Methodological investigation." Journal of organizational Behavior. 11 (5), 361-378.

Roethlisberger, F. J., and Dickson, W. J. (1939). Management and the Worker. Cambridge: Harvard University Press.

Ruekert, R. W., and Walker, O. C. (1987). "Marketing's interaction with other functional units: a conceptual framework and empirical evidence." Journal of Marketing. 51 (1), $1-19$.

Ryan, R. M., and Deci, E. L. (2000). "Intrinsic and Extrinsic Motivations: Classic Definitions and New Directions." Contemporary Educational Psychology. 25, 54-67.

Salancik, G. (1977). "Commitment and the control of organizational behavior and belief." in B. Staw, and G. Salancik (eds.), New directions in organizational behavior. Chicago: St. Clair.

Shipley, David and Kiely, Julia. ( 2007). "Motivation and Dissatisfaction of Industrial Salesperson - How Relevant is Herzberg's Theory?" European Journal of Marketing. 22, (1), $17-30$.

Shore, L. M., and Martin, H. J. (1989). "Job Satisfaction and Organizational Commitment in Relation to Work Performance and Turnover Intentions." Human Relations. 42 (7), 625-638.

Shore, L. M., Newton, L. A., and Thornton, G. C. (1990). "Job and organizational attitudes in relation to employee behavioral intentions." Journal of Organizational behavior. 11 (1).

Siguaw, J., Brown, G., and Widing, R. E. (1994). "The influence of the market orientation of the firm on sales force behavior and attitudes." Journal of Marketing Research. 106116.

Siu, Wai-sum. (2007). "Philosophies of salesforce management in the People's Republic of China: An ethnographic approach." Marketing Intelligence \& Planning. 10, 2, 18- 21. 
Steers, R. M. (1977). "Antecedents and outcomes of organizational commitment." Administrative Science Quarterly. 22, 46-56.

Steers, R., Mowday, R., and Shapiro, D. (2004). "The future of work motivation theory." Academy of Management Review. 29, 379-387.

Strong, E. K. (1925). "Theories of Selling." Journal of Applied Psychology. 9, 75-86.

Tauber, E. M. (1974). "How marketing discourages major innovation." Business Horizons. $17,22-26$.

Vandenberg, R. J., and Lance, C. E. (1992). "Examining the causal order of job satisfaction and organizational commitment." Journal of Management. 18, 153-167.

Wallace, J. E. (1995). "Corporatist control and organizational commitment among professionals: The case of lawyers working in law firms." Social Forces. 73, 811-840.

Ward, E. A., and Davis, E. (1995). "The effect of benefit satisfaction on organizational commitment." Compensation and Benefit Management. 11 (3), 35-40.

Warsi, s., Fatima, N., and Sahibzada, S. A. (2009). "Study on Relationship Between Organizational Commitment and its Determinnants among Private Sector Employees of Pakistan." International Review of Business Research papers. 5 (3), 399-410.

Webster, F. E. (1988). "Rediscovering the marketing concept." Business Horizons. 31, 29-39.

Weiss, A. (1988). "High school graduation, performance, and wages." Journal of Political Economy. 785-820.

Wiener, Y., and Vardi, Y. (1980). "Relationships between job, organization, and career commitment and work outcomes- an integrative approach." Organizational behaviour and Human Performance. 26, 81-96.

Williams, L. J., and Hazer, J. T. (1986). "Antecedents and consequences of satisfaction and commitment in turnover models: A re-analysis using latent variable structural equations models." Journal of Applied Psychology. 71, 219-231.

Winter, R., Taylor, T., and Sarros, J. (2000). "Trouble at mill: quality of academic work issues within a comprehensive Australian university." Studies in Higher Education. $25,279-294$.

Wortman, C. B. (1975). "Some determinants of perceived control." Journal of Personality and Social Psychology. 31, 282-294.

Wren, Brent M., Berkowitz, David, and Grant, E. S. (2014). "Attitudinal, personal, and jobrelated predictors of salesperson turnover." Marketing Intelligence \& Planning, 32,1, $107-123$.

Young, ,. L., and Wilkinson, I. F. (1989). "The role of trust and co-operation in marketing channels: a preliminary study." European Journal of Marketing. 23, 109-122. 